\title{
Interactional role of microRNAs and bHLH-PAS proteins in cancer (Review)
}

\author{
YUMIN LI ${ }^{1,2^{*}}$, YUCAI WEI ${ }^{1,2^{*}}$, JIWU GUO $^{1,2}$, YUSHENG CHENG $^{1,2}$ and WENTING HE ${ }^{1,2}$ \\ ${ }^{1}$ The Second Hospital of Lanzhou University; ${ }^{2}$ Key Laboratory of Digestive System Tumors \\ of Gansu Province, Lanzhou, Gansu 730030, P.R. China
}

Received January 22, 2015; Accepted April 8, 2015

DOI: 10.3892/ijo.2015.3007

\begin{abstract}
MicroRNAs (miRNAs) are recognized as an emerging class of master regulators that regulate human gene expression at the post-transcriptional level and are involved in many normal and pathological cellular processes. Mammalian basic HLH (helix-loop-helix)-PER-ARNT-SIM (bHLH-PAS) proteins are heterodimeric transcriptional regulators that sense and respond to environmental signals (such as chemical pollutants) or to physiological signals (for instance hypoxia). In the normal state, bHLH-PAS proteins are responsible for multiple critical aspects of physiology to ensure the cell accurate homeostasis, but dysregulation of these proteins has been shown to contribute to carcinogenic events such as tumor initiation, promotion, and progression. Increasing epidemiological and experimental studies have shown that bHLH-PAS proteins regulate a panel of miRNAs, whereas some miRNAs also target bHLH-PAS proteins. The interaction between miRNAs and certain bHLH-PAS proteins [hypoxia-inducible factor (HIF) and aryl hydrocarbon receptor (AHR)] is relevant to many vital events associated with tumorigenesis. This review will summarize recent findings on the interesting and complicated underlying mechanisms that miRNAs interact with HIFs or AHR in tumors, hopefully to benefit the discovery of novel drug-interfering targets for cancer therapy.
\end{abstract}

\section{Contents}

1. Introduction

2. miRNAs and bHLH-PAS proteins

3. The potential mechanisms

Correspondence to: Professor Yumin Li, Key Laboratory of Digestive System Tumors of Gansu Province, The Second Hospital of Lanzhou University, 82 Cuiyingmen, Lanzhou, Gansu 730000, P.R. China

E-mail: liym@lzu.edu.cn

*Contributed equally

Key words: microRNA, bHLH-PAS protein, hypoxia-inducible factor, aryl hydrocarbon receptor, cancer
4. Clinical application

5. Conclusions and future directions

\section{Introduction}

miRNAs are small (18-25 nucleotides) non-coding RNAs that degrade target mRNA or suppress its translation by specifically binding to the $3^{\prime}$ untranslated region ( $3^{\prime} \mathrm{UTR}$ ), thus playing a role of gene silencing $(1,2)$. To date, $>1,400$ different miRNAs have been found in humans and regulate $>30 \%$ of mammalian gene expression $(3,4)$. At baseline, miRNAs ensure accurate physiological functions, such as growth, development, differentiation and stress. While, abnormal expression induced by a variety of internal and external factors also plays a pivotal role in tumor origin, proliferation, migration and other pathological processes $(5,6)$.

The bHLH-PAS proteins are heterodimeric transcription factors that form a subgroup of the bHLH superfamily. The bHLH-PAS proteins generally consist of two PAS domains that can sense and respond to environmental signals; for example benzo[a]pyrene $(\mathrm{B}[\mathrm{a}] \mathrm{P})$, , 2,3,7,8-tetrachlorodibenzo-r-dioxin (TCDD) or to physiological signals (such as hypoxia) (7). The bHLH-PAS superfamily includes some very important transcription factors such as AHR, the AHR nuclear translocator (ARNT; also known as HIF1 $\beta$ ), the AHR repressor (AHRR) and different HIFs. Members of the bHLH-PAS family play a broad range role in physiological and pathological processes and take part in multiple cellular signal pathways (8-10). Recent studies have discovered several selective agonists and antagonists that directly target this multifunctional family, presenting a huge potential as an antitumor drug target $(11,12)$.

In recent years, many studies have shown that AHR and HIF can play pro-tumor or antitumor roles. Moreover, the role of miRNAs in tumor origin and development are also focus of attention. Thus, this review focuses on the complicated interactional mechanisms between miRNAs and certain bHLH-PAS proteins (the HIF and AHR) in many vital events relevant to multiple forms of tumors.

\section{2. miRNAs and bHLH-PAS proteins}

Epidemiological and experimental research provides substantial support for the association between bHLH-PAS proteins and miRNAs in cancer (13) (Fig. 1, Tables I and II). miR-210 
is a very important HIF associated miRNA that can be found consistently dysregulated in multiple forms of tumors and is involved in many HIFs associated cellular signal pathways (14-16). Similarly to the transcriptional mechanism of protein encoding genes, the transcription of miRNAs from miRNA genes is regulated by transcription factors, including HIFs and AHR. In breast cancer cells, miRNA sequencing data analysis identified 41 miRNAs significantly upregulated and 28 downregulated under hypoxia. Moreover, study on the transcriptional regulation of miRNA expression by HIFs further illustrated that significantly upregulated miR-210-3p contained a HIF-binding site at its promoter region (17). The promoter regions of miR-155 and miR-373 genes were also found containing HIF-binding site by which hypoxia could promote the transcription of related miRNAs (18). In addition, several transcripts involved in miRNA expressional processes were found to be regulated by hypoxia. For instance, HIF1 regulated the expression of two miRNA transcripts: DICER and AGO4 (17). On the other hand, some miRNAs target HIFs and AHR are involved in the regulation of members in HIFs and AHR signal pathways. Hypoxia regulates the expression of miR-20b, miR-199, miR-210 and miR-424 which can directly target HIFs or control its expression (19-23).

In regards to AHR, Gordon et al reported that the environmental carcinogen $\mathrm{B}[\mathrm{a}] \mathrm{P}$ and $\mathrm{TCDD}$, the xenobiotic AHR ligands, upregulated the expression of a variety of miRNAs in multiple myeloma cells. Importantly, the miR-25 promoter was activated by both $\mathrm{B}[\mathrm{a}] \mathrm{P}$ and TCDD, and this response was mediated by AhR (24).

\section{The potential mechanisms}

Proliferation and cell cycle. miR-210 and miR-21 are upregulated by HIF1 $\alpha$ in a variety of tumors and take part in regulating tumor growth, proliferation and the cell cycle (25). For example, the overexpression of miR-210 induced by HIF $1 \alpha$ could be found in melanoma and lung cancer cells, upregulated miR-210 inhibited proliferation of lung cancer (26). While Li et al reported that upregulated miR-210 facilitated tumor proliferation in epithelial ovarian cancer via targeting protein tyrosine phosphatase, non-receptor type 1 (PTPN1) (27). In addition, inhibition of miR-210 caused cell cycle arrest prior to G2/M in melanoma (28). miR-21 promoted proliferation and overrode hypoxia-induced cell cycle arrest at the G1/S transition (29). In vitro, in vivo and pathological study showed that HIF1 $\alpha$ was a direct target of miR-199 family, downregulated miR-199a was essential for hypoxia induced proliferation by derepressing the expression of HIF1 $\alpha$ and influencing HIFl $\alpha$ mediated the glycolytic pathway in non-small cell lung cancer (NSCLC) (30). While the overexpression of miR-199a and miR-199b, by using virus vectors, significantly downregulated HIF1 $\alpha$ and suppressed cell proliferation in hepatocellular carcinoma (HCC) (31) and prostate cancer (32), respectively. Zhang et al demonstrated that miR-135b promoted tumor proliferation and colony formation through targeting factor inhibiting HIF (FIH) and activating HIF1 $\alpha$ in head and neck squamous cell carcinoma (HNSCC) (33). In addition, Taguchi et al showed that overexpression of miR-17-92 induced by c-myc directly targeted HIF1 $\alpha$ and played a role in cancer cell proliferation (34).
Regarding AHR, Trivellin et al reported that miR-107 was overexpressed in pituitary adenoma samples, and the overexpression of miR-107 inhibited cell proliferation through directly targeting the AHR-interacting protein (AIP) (35). When exposed to $\mathrm{B}[\mathrm{a}] \mathrm{P}$, the expression levels of miR-320 and miR-494 were upregulated and repressed the expression of cyclin-dependent kinase 6 (CDK6), which regulates cell cycle progression by impacting G1/S transition (36). Yuan et al identified ARNT as a novel target of miR-221, and found that delivery of the miR-221 mimics into primary hepatocytes and overexpression of miR-221 mediated by adeno-associated virus in the mouse liver could significantly promote proliferation by targeting ARNT, and suppressed the cell cycle regulator p27 (37).

Angiogenesis. Angiogenesis plays a key role in tumor growth and metastasis (38). bHLH-PAS proteins regulate several angiogenic growth factors through transcriptional modulation, such as the well-known angiogenesis inducer, the vascular endothelial growth factor (VEGF) (39-41). On one hand, bHLH-PAS proteins contribute to vascular homeostasis under adverse environment including toxins and hypoxia, on the other, bHLH-PAS proteins promote angiogenesis in various types of tumors.

He et al found that miR-199a-5p expression levels were significantly downregulated in arsenic transformed cells, and demonstrated that arsenic promoted tumor growth and angiogenesis due to low expression of miR-199a-5p caused loss of control on its direct targets HIFl $\alpha$ and its downstream target COX-2 in vitro and in vivo (19). In low-oxygen conditions, miR-320 was downregulated by HIF1 $\alpha$ in human umbilical vein endothelial cells (HUVECs) and attenuated the inhibitory effect on its target Neuropilin 1, an important regulator of angiogenesis, thus promoting angiogenesis (42). The interaction between HIF and VEGF regulates tumor angiogenesis and enables tumor cells to adapt to different oxygen concentrations (43). Recent studies illustrate miRNAs are also involved in the HIF/VEGF network $(20,44,45)$. For instance, miR-199a and miR-125b were downregulated in ovarian cancer tissues and cell lines and negatively correlated with tumor angiogenesis via HIF1 $\alpha$ /VEGF pathway (46). Overexpression of miR-22 inhibited HIF1 $\alpha$ expression, repressing VEGF production during hypoxia. Conversely, knockdown of endogenous miR-22 enhanced hypoxia-induced expression of HIF1 $\alpha$ and VEGF (47). In addition to the inhibitory effects of miR-503 on angiogenesis through directly targeting two most potent angiogenic factors: fibroblast growth factor-2 (FGF2) and VEGFA (48), miR-128 and miR-145 were demonstrated to attenuate tumor angiogenesis by targeting p70S6K1 and suppressing the downstream signaling molecules HIF1 and VEGF $(49,50)$. When induced by hypoxia, miR-519c resulted in a significant decrease of HIF1 $\alpha$ protein levels and reduced the tube formation of HUVECs. Similarly, inhibition of miR$519 \mathrm{c}$ by antagonist increased the level of HIF1 $\alpha$ protein and enhanced angiogenic activity (51). Moreover, increased HIF2 $\alpha$ in hypoxia induced the repression of miR-15-16 and promoted angiogenesis in colorectal carcinoma cell lines (52).

Invasion and metastasis. Zhang et al found that AHR modulator TCDD and the 6-methyl-1,3,-trichlorodibenzofuran 


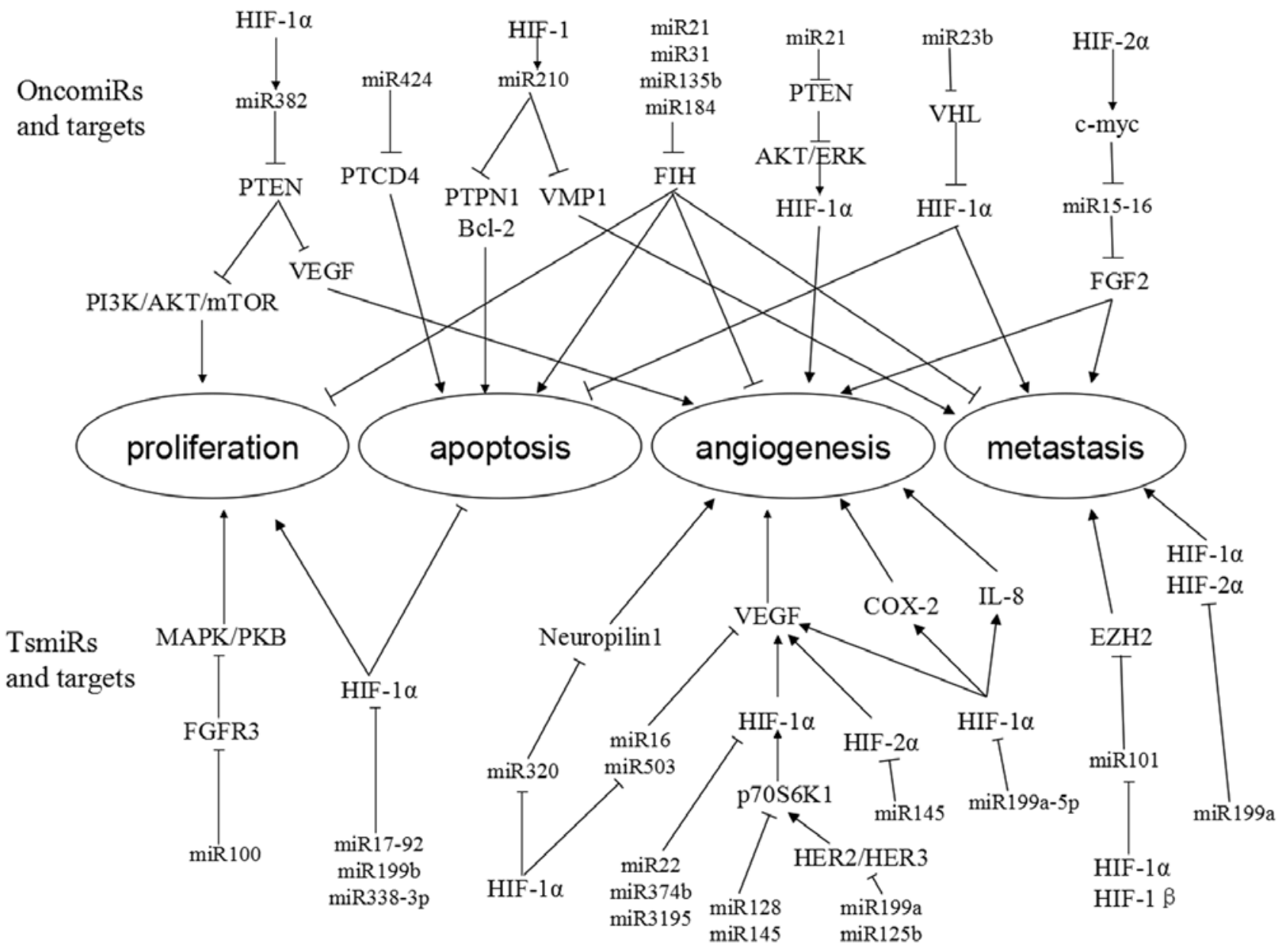

Figure 1. miRNAs involved in HIF-associated carcinogenic processes. Oncogenic miRNAs (oncomiRs) are normally upregulated and directly target or inhibit tumor suppressors, promoting proliferation, angiogenesis, migration and suppressing apoposis. By contrast, tumor suppressor miRNAs (tsmiRs) are often expressed at low level and attenuate the inhibitory effect on oncogenes.

(MCDF) inhibited breast cancer cell invasion by inducing the high expression of miR-335 and repressing a target gene of miR-335: SRY-related high mobility group box 4 (SOX4). Knocking down the AHR inhibited the effects of TCDD and MCDF on miR-335 and SOX4 expression, thus confirming AHR-miR-335 interact to inhibit breast cancer cell metastasis (53). Interestingly, SOX4 was also a target gene of miR-138, the expression of miR-138 inhibited ovarian cancer metastasis via suppressing SOX4 and HIF1 $\alpha$, and overexpression of SOX4 and HIF1 $\alpha$ effectively reversed the miR-138 mediated suppression of cell metastasis (54). In low-oxygen conditions, decreased miR-199a facilitated the metastasis of ovarian cancer cells due to attenuating the inhibitory effect on HIF1 $\alpha$ and HIF2 $\alpha$ (55). Zhang et al reported that downregulated miR-145 inversely correlated with HIF2 $\alpha$ expression in all 20 neuroblastoma samples. While overexpression of miR-145 suppressed tumor invasion and metastasis in vitro and in vivo by directly targeting HIF $2 \alpha$ and promoting the expression of cyclin D1, VEGF and matrix metalloproteinase-14 (MMP-14) (56). miR-23b was demonstrated to induce tumor metastasis by targeting von Hippel-Lindau (VHL) and activating the HIF1 $\alpha /$ VEGF and $\beta$-catenin/Tcf-4 signaling pathways (57). In addition, downregulation of miR-101 by HIF $1 \alpha / \mathrm{HIF} 1 \beta$ enhanced invasion and migration of prostate cancer cells, which may be attributed to the reduced inhibition of enhancer of zeste homolog 2 (Ezh2) by miR-101 (58).

Apoptosis. As a signature miRNA of hypoxia, miR-210 promoted neuroblastoma cell apoptosis via specifically decreasing anti-apoptotic Bcl-2 (59). The upregulation of miR-21 avoided cell apoptosis in pancreatic cancer cells and ovarian cancer cells $(27,29)$. While lentiviral-mediated downregulation of miR-210 expression in hypoxic HCC cells significantly induced apoptosis through directly targeting apoptosis-inducing factor, mitochondrion-associated 3 (AIFM3) (60). In addition, Shang et al showed that miR-199b negatively regulated HIF1 $\alpha$ by targeting its $3^{\prime}$ UTR and promoted apoptosis (32).

Triggering the AhR by agonists such as TCDD and $\mathrm{B}[\mathrm{a}] \mathrm{P}$ decreased expression levels of miR-196a depending on AhR response element (AhRE) binding. While suppressing AHR expression induced miR-196a was able to promote cell apoptosis (61).

Metabolism. In low-oxygen conditions, Louis Pasteur identified a metabolic shift from mitochondrial oxidative phosphorylation to glycolysis that result from repression of the tricarboxylic acid (TCA) cycle, mitochondrial electron 


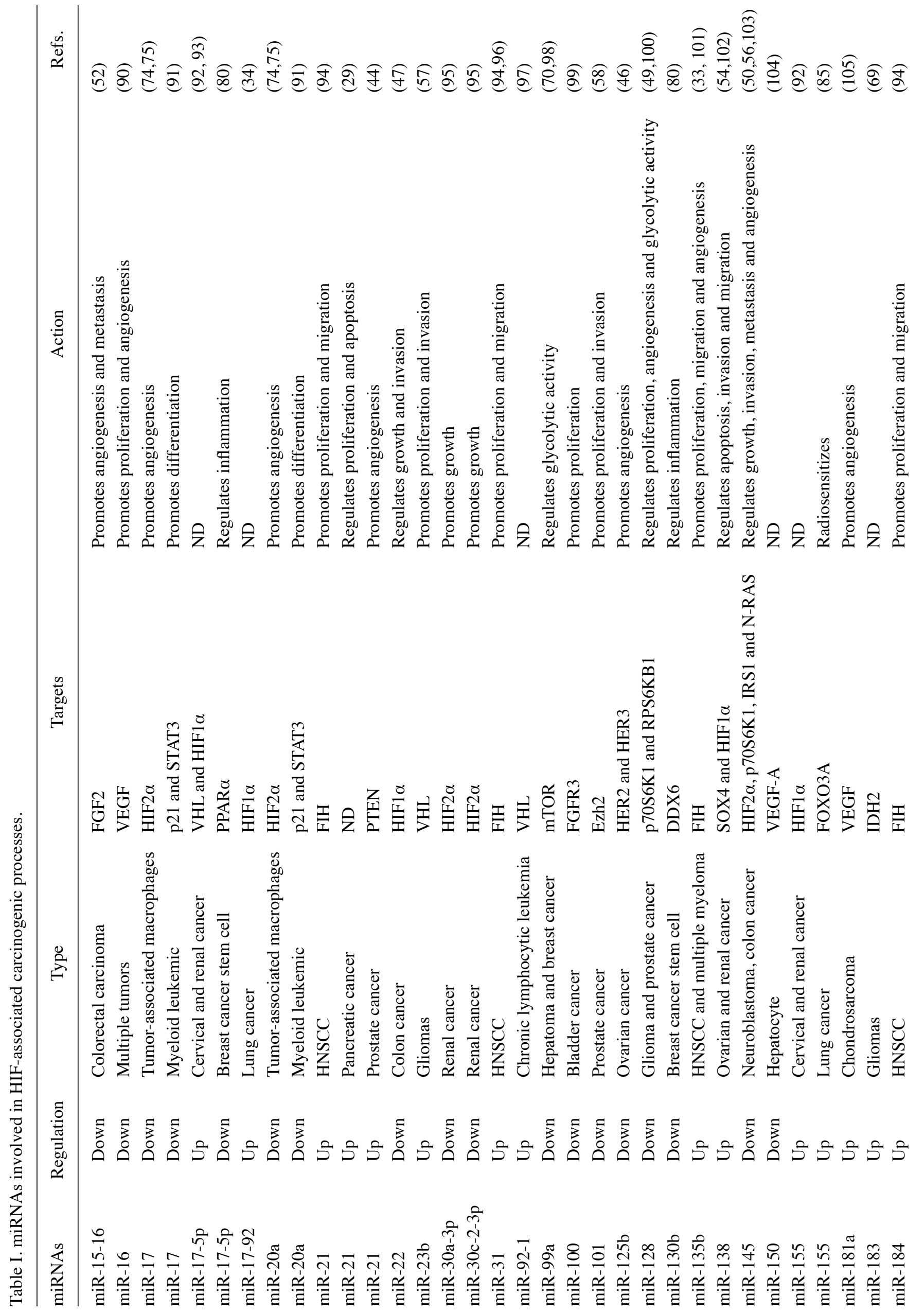




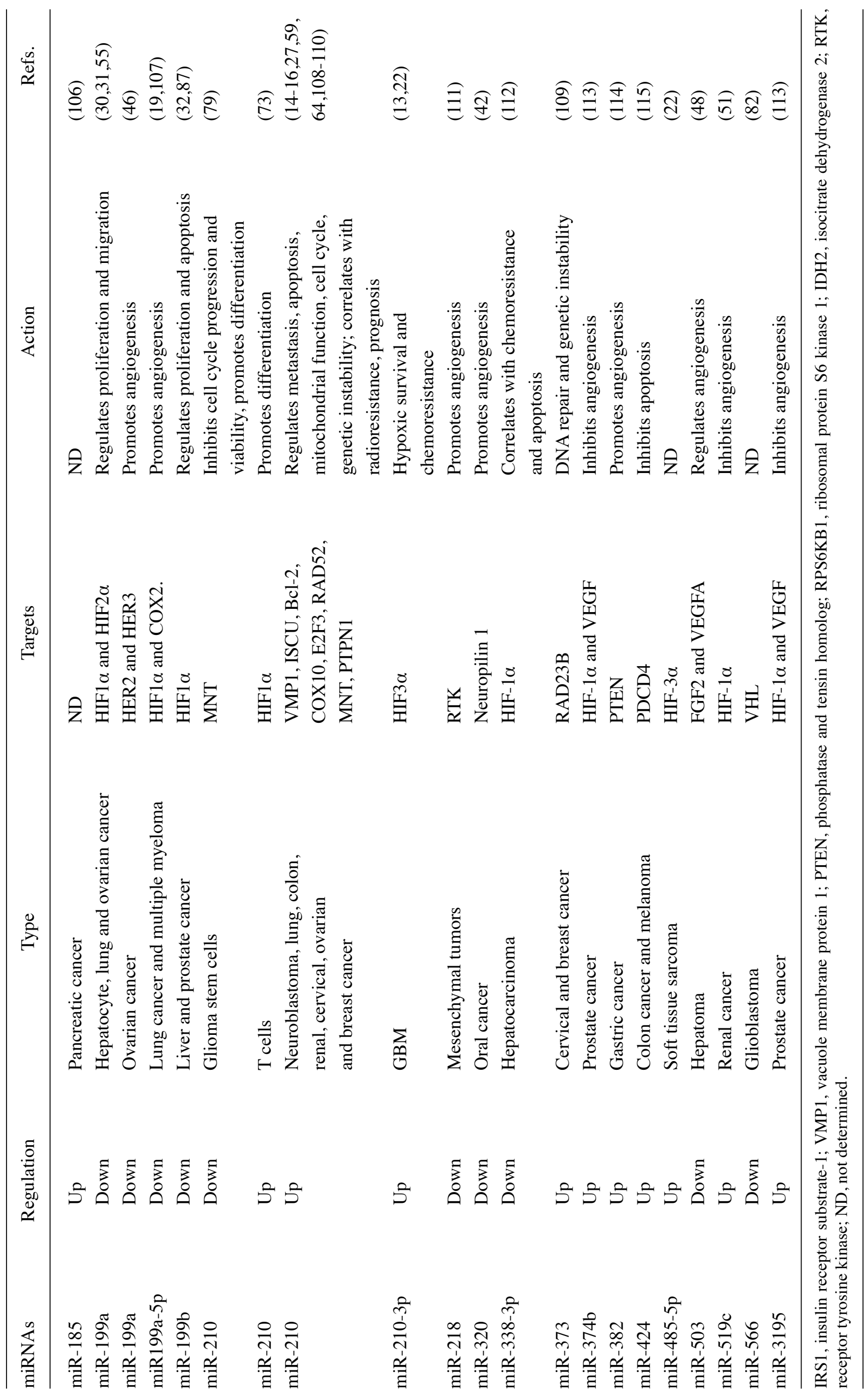


Table II. miRNAs involved in AHRs associated carcinogenic processes.

\begin{tabular}{llllll}
\hline miRNAs & Regulation & \multicolumn{1}{c}{ Type } & Targets & \multicolumn{1}{c}{ action } & Refs. \\
\hline miR-24 & Up & Hepatocellular carcinoma & ARNT & ND & $(116)$ \\
miR-25 & Up & Multiple myeloma & p53 & ND & $(24)$ \\
miR-107 & Up & Pituitary adenomas & AIP & Inhibits proliferation & $(35)$ \\
miR-124 & Down & Neuroblastoma & AHR & Promotes differentiation, cell & $(117)$ \\
& & & cycle arrest and apoptosis & $(89)$ \\
miR-125b & Up & Renal cancer & AhRR & ND & $(61)$ \\
miR-196a & Up & Hepatocellular carcinoma & ARNT & Promotes proliferation & $(37)$ \\
miR-221 & Up & Breast cancer & SOX4 & Inhibits metastasis & $(53)$ \\
miR-335 & Up & Bronchial epithelial cells & AHR & ND & $(77)$ \\
miR-375 & Up & Fibroblast & ND & Inhibits apoptosis & \\
\hline
\end{tabular}

transport, and oxidative phosphorylation (62). Upregulated miR-210 by HIF plays a pivotal role in the regulation of the components that are necessary for this 'Pasteur effect', which can minimize the impact of hypoxia on energy production and benefit tumor growth $(63,64)$. miR-210 caused a shift to glycolysis by controlling a series of components of mitochondrial oxidative phosphorylation, these components included iron-sulfur cluster scaffold homolog (ISCU) (63), COX10 (16), mitochondrial complex I and aconitase $(65,66)$, subunit D of succinate dehydrogenase complex (SDHD) (67), glycerol3-phosphate dehydrogenase 1-like (GPD1-L) (68). In addition to miR-210, miR-183 upregulated HIF1 $\alpha$ by targeting isocitrate dehydrogenase 2 (IDH2): mitochondrial enzymes catalyze the conversion of isocitrate to $\alpha$-ketoglutarate in TCA cycle (69). Downregulated HIF1 $\alpha$ by miR-99a in hepatocarcinoma cells inhibited insulin-induced glucose consumption by suppressing pyruvate kinase M2 (PKM2), a rate-limiting enzyme in the glycolytic pathway (70). miR-203 negatively regulated AHR expression and had a putative binding site in the 3'UTR of indoleamine 2,3-dioxygenase (IDO) (71). IDO is a ratelimiting enzyme in extrahepatic catabolism of tryptophan, thus miR-203 may be involved in AHR/IDO axis-mediated metabolism of tryptophan (72).

Inflammation and immunity. Wang et al reported that there was a negative-feedback between miR-210 and HIF1 $\alpha$ and they could regulate each other. When induced by hypoxia, miR-210 negatively regulated HIF1 $\alpha$ expression and TH17 cell differentiation through reducing HIF1 $\alpha$ transcript abundance and the proportion of cells producing inflammatory cytokines, which could limit immunopathology (73). miR-17 and miR-20a mediated post-transcriptional suppression of HIF $1 \alpha$ and HIF $2 \alpha$ expression in tumor-associated monocytes and macrophages and played an important role during a wide range of cellular physiological as well as pathophysiological processes such as monocyte-to-macrophage differentiation (74,75). Csak et al revealed that downregulation of miR-122 attenuated the inhibitory effect on HIF1 $\alpha$ and played a pathogenic role in steatohepatitis (76).

Bleck et al reported that upregulated miR-375 by environmental pollutants could target AhR and downregulate its expression, thus regulating a pivotal cytokine, thymic stromal lymphopoietin (TSLP), which associated with innate and Th2 adaptive immune disorders (77). The overexpression of miR-132/212 cluster induced by AHR promoted differentiation of Th17 cells by targeting a negative regulator of Th17 differentiation, the B-cell lymphoma 6 (78).

Stem cells. Stem cells are found in all multicellular organisms, that can self-renew and differentiate into diverse specialized cell types, and cancer stem cells are critical drivers of tumor progression (38). Yang et al found that hypoxia led to induction of HIF $2 \alpha$ and miR-210 in glioma stem cells (GSCs), while knocking down of miR-210 decreased stemness, viability, neurosphere formation capacity, invasive capacity and induced differentiation, apoptosis, G0/G1 cell cycle arrest of hypoxic GSCs, and participated in regulating myc-antagonist (MNT) protein expression and caspase-3/7 activity (79). The enhancement of peroxisome proliferator activated receptor- $\alpha$ (PPAR $\alpha)$ and HIF1 $\alpha$ interplay in breast cancer stem cells sustained expression of the pro-inflammatory cytokine interleukin-6 (IL-6), the hypoxia survival factor carbonic anhydrase IX and the plasma lipid carrier apolipoprotein E. Moreover, the PPAR $\alpha /$ HIF1 $\alpha$ interplay was regulated by miR-130b through targeting DDX6 (a HIF1 $\alpha$ translation inhibitory protein) and miR-17-5p via directly targeting PPAR $\alpha$ (80). Overexpression of miR-21 induced by HIF1 $\alpha$ played a positive role for epithelial-mesenchymal transition (EMT), invasion and migration of breast cancer stem cell-like cells (81).

\section{Clinical application}

The resistance of hypoxic cells to radiotherapy and chemotherapy is a major problem in the treatment of cancer. Induction of miR-210 by HIF1 $\alpha$ in hypoxia conferred resistance to radiation via rapidly repairing DNA double-strand breaks after radiation in NSCLC cells (14). The induction of miR-210-3p by HIF1 $\alpha$ in GBM cells showed increased resistance to temozolomide (a chemotherapeutic drug) mediated death while miR-210-3p inhibition made cells more sensitive (13). Inhibition of miR-566 was demonstrated to sensitize GBM cells to nimotuzumab by targeting VHL and activating the $\beta$-catenin/HIF1 $\alpha$ complex which can suppress the activity of epidermal growth factor receptor (EGFR) pathway (82). Bao et al reported that 
the treatment of pancreatic cancer cells with a novel synthetic derivative of curcumin showed an obvious antitumor effect through decreasing gene expression of miR-21, miR-210, IL-6, HIF1 $\alpha$, VEGF under hypoxia $(83,84)$. In low-oxygen conditions, overexpression of miR-155 induced by HIF1 $\alpha$ enhanced radioresistance in lung cancer cells and correlated with poor patient prognosis (85). Pyrrolopyrazine metabolite of oltipraz, a cancer chemopreventive agent, was found to play its antineoplastic function via inducing miR-199a-5p and miR-20a and these two miRNAs mediated inhibition of HIF1 $\alpha$ by preventing its de novo synthesis (86). A case-control study including 35 matched HCCs and cirrhosis tissues showed that underexpressed miR-199b regulated by the upregulation of HIF1 $\alpha$ in HCCs was inversely correlated with survival and directly correlated with the malignant status of HCC patients (87).

$\mathrm{Hu}$ et al demonstrated that upregulation of miR-302 in response to tranilast treatment was dependent on AHR, which was able to bind to miR-302 promoter and active its expression (88). Transcriptionally activated miR-125b by nuclear factor erythroid-2-related factor 2 (Nrf2) served as an inhibitor of AhRR and attenuated its control on AhR, thus, upregulated AhR inhibited p53 activity by targeting an inhibitor of p53 (Mdm2) and contributed to protecting the kidneys from cisplatin-induced injury (89).

\section{Conclusions and future directions}

There is increasing evidence that the bHLH-PAS proteins and its ligands play important roles in cell normal homeostasis and malignant tumor formation. miRNAs can consistently and rapidly sense and respond to environmental and physiological signals (such as $\mathrm{B}[\mathrm{a}] \mathrm{P}$ and hypoxia) by regulating multi-variety of genes and influencing numerous components of cellular signaling pathways extensively and simultaneously, thus research on the interactional role of miRNAs and bHLH-PAS proteins is worthy to clarify the mechanism that underlies the regulation of these environmental and physiological signals. However, the complicated physiological and pathophysiological molecular mechanisms between miRNAs and bHLH-PAS proteins are still unclear. Therefore, further study is needed to uncover the basic mechanisms and should focus on the following directions. First, we need to find more miRNAs and demonstrate their target genes and functions involved in bHLH-PAS proteins. Then, inflammation and stem cells are very valuable and promising fields in cancer. Further in-depth investigations are needed to understand the underlying mechanisms of this interaction in stem cell transformation, CSCs maintainence, and the relationship between inflammation and cancer. The ultimate goal is to look for specific diagnostic markers and selective preventive and therapeutic drugs thus promoting anticancer pharmaceutical development and benefit the prognosis of cancer patients.

\section{Acknowledgements}

This study was supported by the National Natural Science Foundation of China (grant no. 31270532) and Central College Basic Scientific Research Foundation of Lanzhou University (grant no. lzujbky-2013-m04).

\section{References}

1. Lai EC: Micro RNAs are complementary to 3' UTR sequence motifs that mediate negative post-transcriptional regulation. Nat Genet 30: 363-364, 2002.

2. Selbach M, Schwanhäusser B, Thierfelder N, Fang Z, Khanin R and Rajewsky N: Widespread changes in protein synthesis induced by microRNAs. Nature 455: 58-63, 2008.

3. Isomoto H, Matsushima K, Inoue N, Hayashi T, Nakayama T, Kunizaki M, Hidaka S, Nakayama M, Hisatsune J, Nakashima M, et al: Interweaving microRNAs and proinflammatory cytokines in gastric mucosa with reference to $H$. pylori infection. J Clin Immunol 32: 290-299, 2012.

4. Schoof CR, Botelho EL, Izzotti A and Vasques Ldos R: MicroRNAs in cancer treatment and prognosis. Am J Cancer Res 2: 414-433, 2012.

5. Mendell JT and Olson EN: MicroRNAs in stress signaling and human disease. Cell 148: 1172-1187, 2012.

6. Tili E, Michaille JJ and Croce CM: MicroRNAs play a central role in molecular dysfunctions linking inflammation with cancer. Immunol Rev 253: 167-184, 2013.

7. Denison MS, Soshilov AA, He G, DeGroot DE and Zhao B: Exactly the same but different: promiscuity and diversity in the molecular mechanisms of action of the aryl hydrocarbon (dioxin) receptor. Toxicol Sci 124: 1-22, 2011.

8. McIntosh BE, Hogenesch JB and Bradfield CA: Mammalian Per-Arnt-Sim proteins in environmental adaptation. Annu Rev Physiol 72: 625-645, 2010.

9. Feng $\mathrm{S}, \mathrm{Cao} \mathrm{Z}$ and Wang $\mathrm{X}$ : Role of aryl hydrocarbon receptor in cancer. Biochim Biophys Acta 1836: 197-210, 2013.

10. Shen G, Li X, Jia YF, Piazza GA and Xi Y: Hypoxia-regulated microRNAs in human cancer. Acta Pharmacol Sin 34: 336-341, 2013.

11. Hay MP, Hicks KO and Wang J: Hypoxia-directed drug strategies to target the tumor microenvironment. Adv Exp Med Biol 772: 111-145, 2014

12. Safe S, Lee SO and Jin UH: Role of the aryl hydrocarbon receptor in carcinogenesis and potential as a drug target. Toxicol Sci 135: $1-16,2013$.

13. Agrawal R, Pandey P, Jha P, Dwivedi V, Sarkar C and Kulshreshtha R: Hypoxic signature of microRNAs in glioblastoma: Insights from small RNA deep sequencing. BMC Genomics 15: 686, 2014.

14. Grosso S, Doyen J, Parks SK, Bertero T, Paye A, Cardinaud B, Gounon P, Lacas-Gervais S, Noël A, Pouysségur J, et al: MiR-210 promotes a hypoxic phenotype and increases radioresistance in human lung cancer cell lines. Cell Death Dis 4: e544, 2013.

15. Nakada C, Tsukamoto Y, Matsuura K, Nguyen TL, Hijiya N, Uchida T, Sato F, Mimata H, Seto $M$ and Moriyama M: Overexpression of miR-210, a downstream target of HIF1 $\alpha$, causes centrosome amplification in renal carcinoma cells. J Pathol 224: 280-288, 2011.

16. Chen Z, Li Y, Zhang H, Huang P and Luthra R: Hypoxia-regulated microRNA-210 modulates mitochondrial function and decreases ISCU and COX10 expression. Oncogene 29: 4362-4368, 2010.

17. Camps C, Saini HK, Mole DR, Choudhry H, Reczko M, GuerraAssunção JA, Tian YM, Buffa FM, Harris AL, Hatzigeorgiou AG, et al: Integrated analysis of microRNA and mRNA expression and association with HIF binding reveals the complexity of microRNA expression regulation under hypoxia. Mol Cancer 13: 28, 2014.

18. Bruning U, Cerone L, Neufeld Z, Fitzpatrick SF, Cheong A, Scholz CC, Simpson DA, Leonard MO, Tambuwala MM, Cummins EP, et al: MicroRNA-155 promotes resolution of hypoxia-inducible factor 1alpha activity during prolonged hypoxia. Mol Cell Biol 31: 4087-4096, 2011.

19. He J, Wang M, Jiang Y, Chen Q, Xu S, Xu Q, Jiang BH and Liu LZ: Chronic arsenic exposure and angiogenesis in human bronchial epithelial cells via the ROS/miR-199a-5p/HIF-1 $\alpha$ / COX-2 pathway. Environ Health Perspect 122: 255-261, 2014.

20. Lei Z, Li B, Yang Z, Fang H, Zhang GM, Feng ZH and Huang B: Regulation of HIF-1alpha and VEGF by miR-20b tunes tumor cells to adapt to the alteration of oxygen concentration. PLoS One 4: e7629, 2009.

21. Rane S, He M, Sayed D, Vashistha H, Malhotra A, Sadoshima J, Vatner DE, Vatner SF and Abdellatif M: Downregulation of miR-199a derepresses hypoxia-inducible factor-1alpha and Sirtuin 1 and recapitulates hypoxia preconditioning in cardiac myocytes. Circ Res 104: 879-886, 2009. 
22. Gits CM, van Kuijk PF, de Rijck JC, Muskens N, Jonkers MB, van IJcken WF, Mathijssen RH, Verweij J, Sleijfer S and Wiemer EA: MicroRNA response to hypoxic stress in soft tissue sarcoma cells: microRNA mediated regulation of HIF3 $\alpha$. BMC Cancer 14: 429, 2014.

23. Ghosh G, Subramanian IV, Adhikari N, Zhang X, Joshi HP Basi D, Chandrashekhar YS, Hall JL, Roy S, Zeng Y, et al: Hypoxia-induced microRNA-424 expression in human endothelial cells regulates HIF- $\alpha$ isoforms and promotes angiogenesis J Clin Invest 120: 4141-4154, 2010.

24. Gordon MW, Yan F, Zhong X, Mazumder PB, Xu-Monette ZY, Zou D, Young KH, Ramos KS and Li Y: Regulation of p53-targeting microRNAs by polycyclic aromatic hydrocarbons: Implications in the etiology of multiple myeloma. Mol Carcinog: May 6, 2014 (Epub ahead of print). doi: 10.1002/mc.22175.

25. Huang X, Ding L, Bennewith KL, Tong RT, Welford SM, Ang KK, Story M, Le QT and Giaccia AJ: Hypoxia-inducible mir-210 regulates normoxic gene expression involved in tumor initiation. Mol Cell 35: 856-867, 2009.

26. Wang H, Bian S and Yang CS: Green tea polyphenol EGCG suppresses lung cancer cell growth through upregulating miR-210 expression caused by stabilizing HIF-1 $\alpha$. Carcinogenesis 32 : 1881-1889, 2011.

27. Li L, Huang K, You Y, Fu X, Hu L, Song L and Meng Y: Hypoxia-induced miR-210 in epithelial ovarian cancer enhances cancer cell viability via promoting proliferation and inhibiting apoptosis. Int J Oncol 44: 2111-2120, 2014.

28. Hwang HW, Baxter LL, Loftus SK, Cronin JC, Trivedi NS, Borate B and Pavan WJ: Distinct microRNA expression signatures are associated with melanoma subtypes and are regulated by HIF1A. Pigment Cell Melanoma Res 27: 777-787, 2014.

29. Mace TA, Collins AL, Wojcik SE, Croce CM, Lesinski GB and Bloomston M: Hypoxia induces the overexpression of microRNA-21 in pancreatic cancer cells. J Surg Res 184 $855-860,2013$

30. Ding G, Huang G, Liu HD, Liang HX, Ni YF, Ding ZH, Ni GY and Hua HW: MiR-199a suppresses the hypoxia-induced proliferation of non-small cell lung cancer cells through targeting HIF1 $\alpha$. Mol Cell Biochem 384: 173-180, 2013.

31. Jia XQ, Cheng HQ, Qian X, Bian CX, Shi ZM, Zhang JP Jiang BH and Feng ZQ: Lentivirus-mediated overexpression of microRNA-199a inhibits cell proliferation of human hepatocellular carcinoma. Cell Biochem Biophys 62: 237-244, 2012.

32. Shang W, Chen X, Nie L, Xu M, Chen N, Zeng H and Zhou Q miR 199b suppresses expression of hypoxia-inducible factor $1 \alpha$ $(\mathrm{HIF}-1 \alpha)$ in prostate cancer cells. Int J Mol Sci 14: 8422-8436, 2013.

33. Zhang L, Sun ZJ, Bian Y and Kulkarni AB: MicroRNA-135b acts as a tumor promoter by targeting the hypoxia-inducible factor pathway in genetically defined mouse model of head and neck squamous cell carcinoma. Cancer Lett 331: 230-238, 2013.

34. Taguchi A, Yanagisawa K, Tanaka M, Cao K, Matsuyama Y, Goto $\mathrm{H}$ and Takahashi T: Identification of hypoxia-inducible factor-1 alpha as a novel target for miR-17-92 microRNA cluster. Cancer Res 68: 5540-5545, 2008.

35. Trivellin G, Butz H, Delhove J, Igreja S, Chahal HS, Zivkovic V, McKay T, Patócs A, Grossman AB and Korbonits M: MicroRNA miR-107 is overexpressed in pituitary adenomas and inhibits the expression of aryl hydrocarbon receptor-interacting protein in vitro. Am J Physiol Endocrinol Metab 303: E708-E719, 2012.

36. Duan H, Jiang Y, Zhang H and Wu Y: MiR-320 and miR-494 affect cell cycles of primary murine bronchial epithelial cells exposed to benzo[a]pyrene. Toxicol In Vitro 24: 928-935, 2010.

37. Yuan Q, Loya K, Rani B, Möbus S, Balakrishnan A, Lamle J, Cathomen T, Vogel A, Manns MP, Ott M, et al: MicroRNA-221 overexpression accelerates hepatocyte proliferation during liver regeneration. Hepatology 57: 299-310, 2013.

38. Hanahan D and Weinberg RA: Hallmarks of cancer: The next generation. Cell 144: 646-674, 2011.

39. Forsythe JA, Jiang BH, Iyer NV, Agani F, Leung SW, Koos RD and Semenza GL: Activation of vascular endothelial growth factor gene transcription by hypoxia-inducible factor 1 . Mol Cell Biol 16: 4604-4613, 1996

40. Roman AC, Carvajal-Gonzalez JM, Rico-Leo EM and Fernandez-Salguero PM: Dioxin receptor deficiency impairs angiogenesis by a mechanism involving VEGF-A depletion in the endothelium and transforming growth factor-beta overexpression in the stroma. J Biol Chem 284: 25135-25148, 2009.
41. Ceradini DJ, Kulkarni AR, Callaghan MJ, Tepper OM, Bastidas N, Kleinman ME, Capla JM, Galiano RD, Levine JP and Gurtner GC: Progenitor cell trafficking is regulated by hypoxic gradients through HIF-1 induction of SDF-1. Nat Med 10: 858-864, 2004.

42. Wu YY, Chen YL, Jao YC, Hsieh IS, Chang KC and Hong TM: miR-320 regulates tumor angiogenesis driven by vascular endothelial cells in oral cancer by silencing neuropilin 1 . Angiogenesis 17: 247-260, 2014

43. Ramakrishnan S, Anand V and Roy S: Vascular endothelial growth factor signaling in hypoxia and inflammation. J Neuroimmune Pharmacol 9: 142-160, 2014.

44. Liu LZ, Li C, Chen Q, Jing Y, Carpenter R, Jiang Y, Kung HF, Lai L and Jiang BH: MiR-21 induced angiogenesis through AKT and ERK activation and HIF-1 $\alpha$ expression. PLoS One 6: e19139, 2011.

45. Cascio S, D'Andrea A, Ferla R, Surmacz E, Gulotta E, Amodeo V, Bazan V, Gebbia N and Russo A: miR-20b modulates VEGF expression by targeting HIF-1 alpha and STAT3 in MCF-7 breast cancer cells. J Cell Physiol 224: 242-249, 2010.

46. He J, Jing Y, Li W, Qian X, Xu Q, Li FS, Liu LZ, Jiang BH and Jiang Y: Roles and mechanism of miR-199a and miR-125b in tumor angiogenesis. PLoS One 8: e56647, 2013.

47. Yamakuchi M, Yagi S, Ito T and Lowenstein CJ: MicroRNA-22 regulates hypoxia signaling in colon cancer cells. PLoS One 6: e20291, 2011.

48. Zhou B, MaR, Si W, Li S, Xu Y, Tu X and Wang Q: MicroRNA-503 targets FGF2 and VEGFA and inhibits tumor angiogenesis and growth. Cancer Lett 333: 159-169, 2013.

49. Shi ZM, Wang J, Yan Z, You YP, Li CY, Qian X, Yin Y, Zhao P, Wang YY, Wang XF, et al: MiR-128 inhibits tumor growth and angiogenesis by targeting p70S6K1. PLoS One 7: e32709, 2012.

50. Xu Q, Liu LZ, Qian X, Chen Q, Jiang Y, Li D, Lai L and Jiang BH: MiR-145 directly targets p70S6K1 in cancer cells to inhibit tumor growth and angiogenesis. Nucleic Acids Res 40: 761-774, 2012.

51. Cha ST, Chen PS, Johansson G, Chu CY, Wang MY, Jeng YM, Yu SL, Chen JS, Chang KJ, Jee SH, et al: MicroRNA-519c suppresses hypoxia-inducible factor-1alpha expression and tumor angiogenesis. Cancer Res 70: 2675-2685, 2010.

52. Xue G, Yan HL, Zhang Y, Hao LQ, Zhu XT, Mei Q and Sun SH: c-Myc-mediated repression of miR-15-16 in hypoxia is induced by increased HIF-2alpha and promotes tumor angiogenesis and metastasis by upregulating FGF2. Oncogene 34: 1393-1406, 2015.

53. Zhang S, Kim K, Jin UH, Pfent C, Cao H, Amendt B, Liu X, Wilson-Robles $\mathrm{H}$ and Safe $\mathrm{S}$ : Aryl hydrocarbon receptor agonists induce microRNA-335 expression and inhibit lung metastasis of estrogen receptor negative breast cancer cells. Mol Cancer Ther 11: 108-118, 2012.

54. Yeh YM, Chuang CM, Chao KC and Wang LH: MicroRNA-138 suppresses ovarian cancer cell invasion and metastasis by targeting SOX4 and HIF-1alpha. Int J Cancer 133: 867-878, 2013.

55. Joshi HP, Subramanian IV, Schnettler EK, Ghosh G, Rupaimoole R, Evans C, Saluja M, Jing Y, Cristina I, Roy S, et al: Dynamin 2 along with microRNA-199a reciprocally regulate hypoxia-inducible factors and ovarian cancer metastasis. Proc Natl Acad Sci USA 111: 5331-5336, 2014.

56. Zhang H, Pu J, Qi T, Qi M, Yang C, Li S, Huang K, Zheng L and Tong Q: MicroRNA-145 inhibits the growth, invasion, metastasis and angiogenesis of neuroblastoma cells through targeting hypoxia-inducible factor 2 alpha. Oncogene 33: 387-397, 2014.

57. Chen L, Han L, Zhang K, Shi Z, Zhang J, Zhang A, Wang Y, Song Y, Li Y, Jiang T, et al: VHL regulates the effects of miR-23b on glioma survival and invasion via suppression of HIF-1 $\alpha /$ VEGF and $\beta$-catenin/Tcf-4 signaling. Neuro-oncol 14: 1026-1036, 2012

58. Cao P, Deng Z, Wan M, Huang W, Cramer SD, Xu J, Lei M and Sui G: MicroRNA-101 negatively regulates Ezh2 and its expression is modulated by androgen receptor and HIF-1alpha/ HIF-1beta. Mol Cancer 9: 108, 2010.

59. Chio CC, Lin JW, Cheng HA, Chiu WT, Wang YH, Wang JJ, Hsing $\mathrm{CH}$ and Chen RM: MicroRNA-210 targets antiapoptotic Bcl-2 expression and mediates hypoxia-induced apoptosis of neuroblastoma cells. Arch Toxicol 87: 459-468, 2013.

60. Yang W, Sun T, Cao J, Liu F, Tian Y and Zhu W: Downregulation of miR-210 expression inhibits proliferation, induces apoptosis and enhances radiosensitivity in hypoxic human hepatoma cells in vitro. Exp Cell Res 318: 944-954, 2012. 
61. Hecht E, Zago M, Sarill M, Rico de Souza A, Gomez A, Matthews J, Hamid Q, Eidelman DH and Baglole CJ: Aryl hydrocarbon receptor-dependent regulation of miR-196a expression controls lung fibroblast apoptosis but not proliferation. Toxicol Appl Pharmacol 280: 511-525, 2014.

62. Aisenberg AC and Potter VR: Studies on the Pasteur effect. II. Specific mechanisms. J Biol Chem 224: 1115-1127, 1957.

63. Chan SY, Zhang YY, Hemann C, Mahoney CE, Zweier JL and Loscalzo J: MicroRNA-210 controls mitochondrial metabolism during hypoxia by repressing the iron-sulfur cluster assembly proteins ISCU1/2. Cell Metab 10: 273-284, 2009.

64. McCormick RI, Blick C, Ragoussis J, Schoedel J, Mole DR, Young AC, Selby PJ, Banks RE and Harris AL: miR-210 is a target of hypoxia-inducible factors 1 and 2 in renal cancer, regulates ISCU and correlates with good prognosis. Br J Cancer 108: 1133-1142, 2013.

65. Favaro E, Ramachandran A, McCormick R, Gee H, Blancher C Crosby M, Devlin C, Blick C, Buffa F, Li JL, et al: MicroRNA-210 regulates mitochondrial free radical response to hypoxia and krebs cycle in cancer cells by targeting iron sulfur cluster protein ISCU. PLoS One 5: e10345, 2010.

66. He M, Lu Y, Xu S, Mao L, Zhang L, Duan W, Liu C, PiH, Zhang Y, Zhong M, et al: MiRNA-210 modulates a nickel-induced cellular energy metabolism shift by repressing the iron-sulfur cluster assembly proteins ISCU1/2 in Neuro-2a cells. Cell Death Dis 5: e1090, 2014.

67. Puisségur MP, Mazure NM, Bertero T, Pradelli L, Grosso S, Robbe-Sermesant K, Maurin T, Lebrigand K, Cardinaud B, Hofman V, et al: miR-210 is overexpressed in late stages of lung cancer and mediates mitochondrial alterations associated with modulation of HIF-1 activity. Cell Death Differ 18: 465-478, 2011.

68. Fasanaro P, Greco S, Lorenzi M, Pescatori M, Brioschi M, Kulshreshtha R, Banfi C, Stubbs A, Calin GA, Ivan M, et al: An integrated approach for experimental target identification of hypoxia-induced miR-210. J Biol Chem 284: 35134-35143, 2009.

69. Tanaka H, Sasayama T, Tanaka K, Nakamizo S, Nishihara M Mizukawa K, Kohta M, Koyama J, Miyake S, Taniguchi M, et al: MicroRNA-183 upregulates HIF-1 $\alpha$ by targeting isocitrate dehydrogenase 2 (IDH2) in glioma cells. J Neurooncol 111: 273-283, 2013.

70. Li W, Wang J, Chen QD, Qian X, Li Q, Yin Y, Shi ZM, Wang L, Lin J, Liu LZ, et al: Insulin promotes glucose consumption via regulation of miR-99a/mTOR/PKM2 pathway. PLoS One 8: e64924, 2013.

71. Li D, Liu C, Yu H, et al: AhR is negatively regulated by miR-203 in response to TCDD or BaP treatment. Toxicol Res (Camb) 2: $142-151,2013$.

72. Nguyen NT, Nakahama T, Le DH, Van Son L, Chu HH and Kishimoto T: Aryl hydrocarbon receptor and kynurenine: Recent advances in autoimmune disease research. Front Immunol 5: 551, 2014.

73. Wang H, Flach H, Onizawa M, Wei L, McManus MT and Weiss A: Negative regulation of Hifla expression and TH17 differentiation by the hypoxia-regulated microRNA miR-210. Nat Immunol 15: 393-401, 2014.

74. Xu Z, Zhao L, Zhu LY, He M, Zheng L and Wu Y: MicroRNA-17, 20 a regulates the proangiogenic function of tumor-associated macrophages via targeting hypoxia-inducible factor $2 \alpha$. PLoS One 8: e77890, 2013.

75. Poitz DM, Augstein A, Gradehand C, Ende G, Schmeisser A and Strasser RH: Regulation of the Hif-system by micro-RNA 17 and 20a - role during monocyte-to-macrophage differentiation. Mol Immunol 56: 442-451, 2013.

76. Csak T, Bala S, Lippai D, Satishchandran A, Catalano D, Kodys K and Szabo G: microRNA-122 regulates hypoxia-inducible factor- 1 and vimentin in hepatocytes and correlates with fibrosis in diet-induced steatohepatitis. Liver Int 35: 532-541 2015.

77. Bleck B, Grunig G, Chiu A, Liu M, Gordon T, Kazeros A and Reibman J: MicroRNA-375 regulation of thymic stromal lymphopoietin by diesel exhaust particles and ambient particulate matter in human bronchial epithelial cells. J Immunol 190: 3757-3763, 2013.

78. Nakahama T, Hanieh H, Nguyen NT, Chinen I, Ripley B, Millrine D, Lee S, Nyati KK, Dubey PK, Chowdhury K, et al: Aryl hydrocarbon receptor-mediated induction of the microRNA132/212 cluster promotes interleukin-17-producing T-helper cell differentiation. Proc Natl Acad Sci USA 110: 11964-11969, 2013.

79. Yang W, Wei J, Guo T, Shen Y and Liu F: Knockdown of miR-210 decreases hypoxic glioma stem cells stemness and radioresistance. Exp Cell Res 326: 22-35, 2014.
80. Papi A, Storci G, Guarnieri T, De Carolis S, Bertoni S, Avenia N, Sanguinetti A, Sidoni A, Santini D, Ceccarelli C, et al: Peroxisome proliferator activated receptor- $\alpha$ /hypoxia inducible factor- $1 \alpha$ interplay sustains carbonic anhydrase IX and apoliprotein E expression in breast cancer stem cells. PLoS One 8: e54968, 2013.

81. Han M, Wang Y, Liu M, Bi X, Bao J, Zeng N, Zhu Z, Mo Z, Wu C and Chen X: MiR-21 regulates epithelial-mesenchymal transition phenotype and hypoxia-inducible factor- $1 \alpha$ expression in thirdsphere forming breast cancer stem cell-like cells. Cancer Sci 103: 1058-1064, 2012.

82. Zhang KL, Zhou X, Han L, Chen LY, Chen LC, Shi ZD, Yang M, Ren Y, Yang JX, Frank TS, et al: MicroRNA-566 activates EGFR signaling and its inhibition sensitizes glioblastoma cells to nimotuzumab. Mol Cancer 13: 63, 2014

83. Bao B, Ali S, Ahmad A, Azmi AS, Li Y, Banerjee S, Kong D, Sethi S, Aboukameel A, Padhye SB, et al: Hypoxia-induced aggressiveness of pancreatic cancer cells is due to increased expression of VEGF, IL-6 and miR-21, which can be attenuated by CDF treatment. PLoS One 7: e50165, 2012.

84. Bao B, Ahmad A, Kong D, Ali S, Azmi AS, Li Y, Banerjee S, Padhye $\mathrm{S}$ and Sarkar FH: Hypoxia induced aggressiveness of prostate cancer cells is linked with deregulated expression of VEGF, IL- 6 and miRNAs that are attenuated by CDF. PLoS One 7: e43726, 2012.

85. Babar IA, Czochor J, Steinmetz A, Weidhaas JB, Glazer PM and Slack FJ: Inhibition of hypoxia-induced miR-155 radiosensitizes hypoxic lung cancer cells. Cancer Biol Ther 12: 908-914, 2011.

86. Kang SG, Lee WH, Lee YH, Lee YS and Kim SG: Hypoxiainducible factor- $1 \alpha$ inhibition by a pyrrolopyrazine metabolite of oltipraz as a consequence of microRNAs 199a-5p and 20a induction. Carcinogenesis 33: 661-669, 2012

87. Wang C, Song B, Song W, Liu J, Sun A, Wu D, Yu H, Lian J, Chen L and Han J: Underexpressed microRNA-199b-5p targets hypoxia-inducible factor- $1 \alpha$ in hepatocellular carcinoma and predicts prognosis of hepatocellular carcinoma patients. J Gastroenterol Hepatol 26: 1630-1637, 2011.

88. Hu W, Zhao J and Pei G: Activation of aryl hydrocarbon receptor (ahr) by tranilast, an anti-allergy drug, promotes miR-302 expression and cell reprogramming. J Biol Chem 288: 22972-22984, 2013.

89. Joo MS, Lee CG, Koo JH and Kim SG: miR-125b transcriptionally increased by Nrf2 inhibits AhR repressor, which protects kidney from cisplatin-induced injury. Cell Death Dis 4: e899. 2013.

90. Dejean E, Renalier MH, Foisseau M, Agirre X, Joseph N, de Paiva GR, Al Saati T, Soulier J, Desjobert C, Lamant L, et al: Hypoxia-microRNA-16 downregulation induces VEGF expression in anaplastic lymphoma kinase (ALK)-positive anaplastic large-cell lymphomas. Leukemia 25: 1882-1890, 2011.

91. He M, Wang QY, Yin QQ, Tang J, Lu Y, Zhou CX, Duan CW, Hong DL, Tanaka T, Chen GQ, et al: HIF-1 $\alpha$ downregulates miR-17/20a directly targeting p21 and STAT3: A role in myeloid leukemic cell differentiation. Cell Death Differ 20: 408-418, 2013.

92. Bertozzi D, Marinello J, Manzo SG, Fornari F, Gramantieri L and Capranico G: The natural inhibitor of DNA topoisomerase I, camptothecin, modulates HIF- $1 \alpha$ activity by changing miR expression patterns in human cancer cells. Mol Cancer Ther 13: 239-248, 2014

93. Lichner Z, Mejia-Guerrero S, Ignacak M, Krizova A, Bao TT, Girgis AH, Youssef YM and Yousef GM: Pleiotropic action of renal cell carcinoma-dysregulated miRNAs on hypoxia-related signaling pathways. Am J Pathol 180: 1675-1687, 2012.

94. Kao SY, Tsai MM, Wu CH, Chen JJ, Tseng SH, Lin SC and Chan KW: Co-targeting of multiple microRNAs on factor-inhibiting hypoxia-inducible factor $(\mathrm{FIH})$ gene for the pathogenesis of head and neck carcinomas. Head Neck: Oct 28, 2014 (Epub ahead of print). doi: 10.1002/hed.23912.

95. Mathew LK, Lee SS, Skuli N, Rao S, Keith B, Nathanson KL, Lal P and Simon MC: Restricted expression of miR-30c-2-3p and miR-30a-3p in clear cell renal cell carcinomas enhances HIF $2 \alpha$ activity. Cancer Discov 4: 53-60, 2014.

96. Liu CJ, Tsai MM, Hung PS, Kao SY, Liu TY, Wu KJ, Chiou SH, Lin SC and Chang KW: miR-31 ablates expression of the HIF regulatory factor FIH to activate the HIF pathway in head and neck carcinoma. Cancer Res 70: 1635-1644, 2010.

97. Ghosh AK, Shanafelt TD, Cimmino A, Taccioli C, Volinia S, Liu CG, Calin GA, Croce CM, Chan DA, Giaccia AJ, et al: Aberrant regulation of pVHL levels by microRNA promotes the HIF/VEGF axis in CLL B cells. Blood 113: 5568-5574, 2009. 
98. Yang Z, Han Y, Cheng K, Zhang G and Wang X: miR-99a directly targets the mTOR signalling pathway in breast cancer side population cells. Cell Prolif 47: 587-595, 2014.

99. Blick C, Ramachandran A, Wigfield S, McCormick R, Jubb A, Buffa FM, Turley H, Knowles MA, Cranston D, Catto J, et al: Hypoxia regulates FGFR3 expression via HIF-1 $\alpha$ and miR-100 and contributes to cell survival in non-muscle invasive bladder cancer. Br J Cancer 109: 50-59, 2013.

100. Tao T, Li G, Dong Q, Liu D, Liu C, Han D, Huang Y, Chen S, $\mathrm{Xu} \mathrm{B}$ and Chen M: Loss of SNAIL inhibits cellular growth and metabolism through the miR-128-mediated RPS6KB1/ HIF-1alpha/PKM2 signaling pathway in prostate cancer cells. Tumour Biol 35: 8543-8550, 2014.

101. Umezu T, Tadokoro H, Azuma K, Yoshizawa S, Ohyashiki K and Ohyashiki JH: Exosomal miR-135b shed from hypoxic multiple myeloma cells enhances angiogenesis by targeting factor-inhibiting HIF-1. Blood 124: 3748-3757, 2014.

102. Song T, Zhang X, Wang C, Wu Y, Cai W, Gao J and Hong B: MiR-138 suppresses expression of hypoxia-inducible factor 10 (HIF-1 $\alpha$ ) in clear cell renal cell carcinoma 786-O cells. Asian Pac J Cancer Prev 12: 1307-1311, 2011.

103. Yin Y, Yan ZP, Lu NN, Xu Q, He J, Qian X, Yu J, Guan X, Jiang BH and Liu LZ: Downregulation of miR-145 associated with cancer progression and VEGF transcriptional activation by targeting N-RAS and IRS1. Biochim Biophys Acta 1829: 239-247, 2013.

104. Yu ZY, Bai YN, Luo LX, Wu H and Zeng Y: Expression of microRNA-150 targeting vascular endothelial growth factor-A is downregulated under hypoxia during liver regeneration. Mol Med Rep 8: 287-293, 2013

105. Sun X, Wei L, Chen Q and Terek RM: MicroRNA regulates vascular endothelial growth factor expression in chondrosarcoma cells. Clin Orthop Relat Res 473: 907-913, 2014.

106. Song Z, Ren H, Gao S, Zhao T, Wang X, Zhang S, Zhao X, Jia L, Sun J and Hao J: The hypoxia-inducible factor-1 regulates the microRNA185 expression through binding to hypoxia response elements sequence 2. Med Oncol 30: 756, 2013.

107. Raimondi L, Amodio N, Di Martino MT, Altomare E, Leotta M, Caracciolo D, Gullà $\mathrm{A}$, Neri $\mathrm{A}$, Taverna $\mathrm{S}, \mathrm{D}$ 'Aquila $\mathrm{P}$, et al: Targeting of multiple myeloma-related angiogenesis by miR199a-5p mimics: In vitro and in vivo anti-tumor activity. Oncotarget 5: 3039-3054, 2014.
108. Qu A, Du L, Yang Y, Liu H, Li J, Wang L, Liu Y, Dong Z, Zhang X, Jiang X, et al: Hypoxia-inducible MiR-210 is an independent prognostic factor and contributes to metastasis in colorectal cancer. PLoS One 9: e90952, 2014.

109. Crosby ME, Kulshreshtha R, Ivan M and Glazer PM: MicroRNA regulation of DNA repair gene expression in hypoxic stress. Cancer Res 69: 1221-1229, 2009.

110. Kim HW, Haider HK, Jiang S and Ashraf M: Ischemic preconditioning augments survival of stem cells via miR-210 expression by targeting caspase-8-associated protein 2 . J Biol Chem 284: 33161-33168, 2009.

111. Mathew LK, Skuli N, Mucaj V, Lee SS, Zinn PO, Sathyan P, Imtiyaz HZ, Zhang Z, Davuluri RV, Rao S, et al: miR-218 opposes a critical RTK-HIF pathway in mesenchymal glioblastoma. Proc Natl Acad Sci USA 111: 291-296, 2014.

112. Xu H, Zhao L, Fang Q, Sun J, Zhang S, Zhan C, Liu S and Zhang Y: MiR-338-3p inhibits hepatocarcinoma cells and sensitizes these cells to sorafenib by targeting hypoxia-induced factor 1 $\alpha$. PLoS One 9: e115565, 2014.

113. Sohn EJ, Won G, Lee J, Lee S and Kim SH: Upregulation of miRNA3195 and miRNA374b mediates the anti-angiogenic properties of melatonin in hypoxic PC-3 prostate cancer cells. J Cancer 6: 19-28, 2015.

114. Seok JK, Lee SH, Kim MJ and Lee YM: MicroRNA-382 induced by HIF-1 $\alpha$ is an angiogenic miR targeting the tumor suppressor phosphatase and tensin homolog. Nucleic Acids Res 42: 8062-8072, 2014.

115. Zhang D, Shi Z, Li M and Mi J: Hypoxia-induced miR-424 decreases tumor sensitivity to chemotherapy by inhibiting apoptosis. Cell Death Dis 5: e1301, 2014.

116. Oda Y, Nakajima M, Mohri T, Takamiya M, Aoki Y, Fukami T and Yokoi T: Aryl hydrocarbon receptor nuclear translocator in human liver is regulated by miR-24. Toxicol Appl Pharmacol 260: 222-231, 2012.

117. Huang TC, Chang HY, Chen CY, Wu PY, Lee H, Liao YF, Hsu WM, Huang HC and Juan HF: Silencing of miR-124 induces neuroblastoma SK-N-SH cell differentiation, cell cycle arrest and apoptosis through promoting AHR. FEBS Lett 585: 3582-3586, 2011. 